\title{
III. The Water Beetles of Japan.
}

\section{By David Sharp, M.B.}

[Read 6th January, 1873.]

Mr object in this paper is to enumerate the species of Dytiscidæ and Hydrophilidæ found by Mr. George Lewis in Japan. To enable me to do this Mr. Lewis has entrusted me with the whole of the specimens belonging to these families, captured by him during his residence in the Japanese islands. To the students of the European fauna these Japanese insects are of very great interest: the number of species common to Europe and these far distant islands is by no means inconsiderable; other European species are represented in Japan by closely allied forms, and some of our larger genera possess there numerous species. Mingled with these European forms we find a large proportion of quite Eastern genera and species. It must be remembered that we know comparatively little of the beetles of central and eastern Asia, especially of those parts contiguous to the Japanese islands, so that at present we are not in a position to form any correct opinion as to what proportion the European forms bear to the eastern ones in these parts. It will probably, however, ultimately be found that the faunas of the eastern and western portions of the old world gradually merge into one another, and should really be considered but as one fauna. The species here enumerated belong to twenty-five genera, of which three are unrepresented in the European or Mediterranean fauna; these three are all genera of a wide distribution.

\section{DytisCIDÆ.}

1. Cybister japonicus, n. sp. Sat convexus, latior, ovalis postice dilatatus, supra nigro-olivaceus, capite antice, prothoracis lateribus, vittâque longitudinali versus elytrorum marginem testaceis; subtus testaceus, pectore medio late olivaceo, suturis, abdominisque segmentis anguste nigro-marginatis.

Long. 18 lin.; lat. $9 \frac{1}{2}-10$ lin.; alt. $5 \frac{1}{3}$ lin.

Mas, prothorace elytrisque lævibus.

Fem., prothorace reticulato-strigoso, elytris excepte ad apicem reticulato-striatis.

TRANS. ENT. SOC. 1873.-PART I. (MAR.) 
This species is closely allied to the European C.Roselii; the sculpture of the female is very similar in the two species. C. japonicus is considerably larger, broader, and more convex; the upper surface is less green in colour than in Roselii. The large and well defined dark mark on the breast, and the dark sutures of the under surface, are also good points of distinction. In the female the dilatation of the epipleuræ of the elytra near the base is very remarkable, and much greater than in Roselii. Abundant* throughout Nipon and Kushiu.

2. Cybister Lewisianus, n. sp. Convexus, ovatus, antice minus angustatus, supra olivaceus, labro lateribusque prothoracis et elytrorum testaceis ; subtus rufo-testaceus, pectoris marginibus anguste nigricantibus; pedibus testaceis, tarsis intermediis, tibiis tarsisque posterioribus nigro-piceis. Long. 11 lin.; lat. 6 lin. : alt. $3 \frac{3}{4}$ lin.

Mas, prothorace elytrisque lævibus.

Femina latet.

This species is not at all closely allied to any described species I am acquainted with; it belongs to Aubé's section $b$, having the sides and epipleuræ of the elytra yellow, without any intersecting dark colour. The antennæ are yellow, with the four or five apical joints pitchy, except at their extremities. Palpi yellow, with the apical joint a little darkened. Head of a dark olivaceous colour, with the labrum, and a broad triangular mark above it, yellow ; the orbit of the eyes is also yellow, narrowly so behind, but at the front part, where it is connected with the other yellow mark, broadly so ; it appears to be quite smooth and shining, but, when examined with a strong magnifying power, is found to be very finely coriaceous, and to have other larger, fine points sparingly scattered over it. The thorax is broadly margined with yellow; it has the usual punctures at the sides and front, and is sculptured in a similar manner to the head, but the fine scattered points are even smaller and less numerous. The scutellum is yellowish in the middle. The elytra are of a dark olivaceous colour, with a bright yellow margin; this stripe is a little dilated at the extreme base; it is narrowed in its posterior third, and a little before the extremity are a few

* I am greatly indebted to Mr. Lewis for enriching this paper with information as to the localities, and rarity or abundance of the species mentioned in it. 
obscure yellow points not distinctly connected with the stripe. The three usual lines of punctures are very distinct, the external row less so than the two others; the two or three basal points of the external row are placed in the yellow lateral stripe, the three or four following ones just at its edge. The underside of the head is pitchy red, with the parts of the mouth yellowish. The prosternum is reddish-yellow; the front legs are entirely yellow; the middle of the breast is reddish; the intermediate portion yellow; the extreme outer margin (very narrowly) black. The middle legs are yellow, with the tibiæ slightly darker than the femora; their tarsi pitchy black; their outer claw larger than the inner one. The abdomen is reddish; the hind margins of the segments narrowly pitchy; the extreme sides also a little pitchy, and the basal segments with a pale spot at the sides. The hind femora are reddish; the tibiæ and tarsi pitchy black; the spurs of the former reddish.

The much more convex form, and the different colour of the insect beneath, will prevent this species being confounded with any of the forms of C. tripunctatus. It is also very different in form from $C$. scutellaris, from which morever the unequal claws of the intermediate tarsi readily separate it (as far as the male sex is concerned, at any rate). A single specimen only has been found, at Mino, near Osaka.

3. Gybister tripunctatus, Ol. Abundant in Nipon and Kushiu. These Japanese specimens cannot be considered specifically identical with our European C. africanus, which is now considered a form of tripunctatus ; they may indeed ultimately prove to be a distinct species from any yet described; but it would be premature to consider them so at present, so much yet remaining to be done for the accurate discrimination of these difficult and variable species.

4. Cybister brevis, Aubé. Abundant in Nipon and Kushiu. This species was described by Aubé from a single female individual. He supposed the male would not possess the remarkable punctuation on the head and thorax which he described in the female; but in this he was wrong, the sexes are similar in every external point except the structure of the tarsi.

5. Hydaticus Adamsi, Clark. Rather rare; under 
stones on Mitsuyama, Nagasaki, and from ponds at Osaka. This species has been identified by Mr. Lewis, by comparison with specimens in the British Museum.

6. Hydaticus vittatus, Fab. Very common in Kushiu and Nipon. It is quite probable that several closely allied species are confounded under the name of vittatus. We must wait, however, till series of individuals from various localities can be examined before deciding this point.

7. Hydaticus rufulus, Aubé. Nagasaki and Hiogo. This species is united in the Munich catalogue with our European $H$. Leander, but I entertain doubts as to the correctness of this.

8. Hydaticus grammicus, Germ. Nagasaki.

9. Hydaticus japonicus, n. sp. Breviter ovatus, convexus, capite prothoraceque testaceis, nigro signatis, elytris nigricantibus flavo-irroratis ; subtus nigro-piceus, prothoracis lateribus, prosterno, pedibus quatuor anticis epipleurarumque basi testaceis, pedibus posterioribus nigris femoribus flavo-ornatis. Long. $5 \frac{3}{4}-6 \frac{1}{2}$ lin.; lat. $3 \frac{3}{4}-$ 4 lin.

Mas, tarsis anticis et intermediis dilatatis.

This species will be best described by a comparison with $H$. cinereus, to which it is closely allied. The colouring of the upper surface is just the same as in cinereus, but beneath, japonicus is very much darker, and the form of japonicus is very much shorter than that of cinereus.

The female differs from the male by its simple tarsi, by possessing a few obscure lines or strigæ near the sides of the thorax, and also by the yellow band of the middle of the thorax being narrower than in the other sex.

Very abundant in the fens of Osaka and the ponds of Hiogo.

10. Colymbetes pulverosus, Steph. Widely distributed and abundant.

11. Agabus conspicuus, n. sp. Latior, ovatus, convexus, supra subtiliter reticulatus, capite prothoraceque nigro-æneis, illo maculis duabus rufis, elytris fuscis, marginibus dilutioribus; subtus subtiliter strigosulus, niger. Long. $5 \frac{1}{2}$ lin.; lat. 3 в lin.

Mas, unguiculis anticis longitudine subæqualibus, an- 
teriore (vel interiore) leviter dilatato ante basin emarginato.

This very distinct and interesting Agabus is allied to both $A$. bipustulatus and fuscipennis, while in the structure of the claws of the hind feet it makes an approach to Ilybius. It is readily distinguished from fuscipennis by the larger size and the rounded base of the thorax, as well as by the distinct reticulation of the elytra. It is broader and more rounded at the sides than is A. bipustulatus, and the reticulation of its upper surface is quite different from that species, being much finer, and the direction of the lines transverse rather than longitudinal; the sculpture of the under surface much resembles that of bipustulatus. The shape of the lateral laciniæ of the metasternum is rather close to that of $A$. fuscipennis, but the depth of the hind coxæ is considerably more than in fuscipennis; this arises both from their upper margin being more strongly arched, and their lower margin more transverse (that is, less oblique in direction) than in fuscipennis. The claws of the hind tarsi are closely applied to one another, and almost straight, the outer one is evidently smaller than the inner one; the disparity, however, is much less than in Ilybius. The species is rather variable in its colour.

Osaka and Nagasaki. Common.

12. Agabus (Platambus, Th.) pictipennis, n.sp. Ovalis, supra nitidissimus, nigricans, capite maculis duabus, antennis pedibusque rufis; elytris basi fasciâ ad scutellum interruptâ et utrinque versus latus maculis tribus pallidis; prothorace angulis posterioribus subacutis; subtus ferrugineus. Long. $3 \frac{1}{2}$ lin.

Mas, tarsis anticis vix dilatatis, unguiculis simplicibus.

This species has all the structure assigned by Thomson to the genus Platambus. It is readily distinguished from A. maculatus by the shining and nearly unsculptured upper surface, as well as by the different markings; in this latter respect it appears more allied to $A$. sinuatus, Aubé (from Asia Minor), a species which I have not seen, but which, judging from description, should be similar in sculpture to maculatus, and therefore very different from pictipennis; sinuatus has, moreover, at the sides of the elytra a continuous pale band instead of the three spots of

TRANS. ENT. SOC. 1873.-PART I. (MAR.) 
pictipennis. The colour, both of the upper and under surfaces, varies according to the degree of maturity.

Four specimens from Hiogo, under stones in the watercourses.

13. Agabus japonicus, n. sp. Ex affinitate A. paludosi: ovalis, supra nitidus, lævis, capite prothoraceque nigro-æneis, elytris fuscis: subtus niger. Long. $3 \frac{1}{2}$ $3 \frac{3}{4}$ lin.

Mas, tarsis anticis vix dilatatis, unguiculis æqualibus simplicibus; tarsis posterioribus articulis tribus basalibus subtus minus dense setigeris.

This species is closely allied to A. paludosus; it is broader and more rounded at the sides, the thorax is of an obscure brassy colour, and not paler at the sides, and its hind angles are more acute; the impressed points on the elytra are finer.

The underside is black, with the epipleuræ pale at the base. The antennæ and palpi are reddish-yellow, the four front legs are reddish, with the femora infuscate; the femora and tibiæ of the hind legs are blackish, their tarsi reddish. The structural characters of the male are similar to those of paludosus.

Hiogo and Nagasaki.

14. Agabus dissimilis, n. sp. Ex affinitate A. spilopteri, Germ.-Late ovalis, depressus, niger, nitidus, subtilissime reticulatus; capite, prothoracis maculâ ad angulum anteriorem, antennis, pedibusque quatuor anticis rufotestaceis; pedibus posterioribus piceis. Long. $2 \frac{1}{2}$ lin.; lat. $1 \frac{1}{2}$ lin.

Variat, elytris plus minusve testaceo-ornatis.

This insect has more the form of a large Laccophilus than of an Agabus. It is allied to A. spilopterus, Germ. It is very shining, the upper surface is finely reticulate, the head is yellowish, the part adjacent to the inner margin of the eye broadly marked with black. The thorax has a large yellowish mark at the front angle. The elytra are also marked with yellow, but apparently in a very variable degree; there being either a narrow yellow transverse band close to the base; or this is absent, and replaced by one or two small pale dots; just in front of the apex there is always a yellow spot, and the parts towards the sides and the extremity show also some obscure and 
variable yellow marks. The lateral laciniæ of the metasternum are extremely narrow.

Three examples of this interesting species have been submitted to me by $\mathrm{Mr}$. Lewis, without particular locality being indicated.

15. Copelatus, spec.? There are two specimens of this genus in the collection, one male (from Osaka), one female (from Nagasaki); I have been unable to satisfy myself that they are certainly the same species, and I do not therefore describe them. Mr. Lewis feels sure they are distinct species, and I think it very likely to prove so.

16. Ilybius apicalis, n. sp. Oblongo-ovalis, supra æneus, margine pallescente ante apicem trihamato; subtus ferrugineus; metasterni laciniis perangustis. Long. $4 \frac{1}{3}$ lin.; lat. $2 \frac{1}{4}$ lin.

This species resembles in form $I$. fuliginosus, but is readily to be distinguished by the band of the elytra, which has a large treble spot attached to it at the extremity, and by the very different shape of the side wings of the metasternum. The upper surface is brassy, with the front of the head, the sides of the thorax and elytra yellowish; the pale band of the elytra is divided in its posterior part by a darker line, and a little behind the middle there is close to the band a short pale dash; the sculpture of the upper surface is very fine and dense. The under surface is of a rusty colour, the antennæ and legs reddish-yellow. The anterior margin of the hind coxæ is very much extended forwards, more so even than in fenestratus.

The structure of the claws in the male does not differ from that of the female; the outer claw of the hind foot is slender and but little curved.

Ponds in sandy districts. Hiogo and Simabara. Rare.

17. Hydrocanthus politus, n. sp. Ovalis, nitidus, lævis, testaceus, elytris fuscis, testaceo-maculatis; prosterno pectorisque parte elevatâ fortiter punctatis. Long. $1 \frac{1}{4}$ lin.

Entirely shining yellow, with the exception of the elytra, which are blackish, but largely marked with yellow; these markings consist of two very large yellow spots at the base, and a transverse band placed a little behind the middle and interrupted at the suture, the extremity also 
is pale. The upper surface is very shining and quite without sculpture, while the whole of the raised portion of the under surface is strongly punctured.

Common in ponds at Hiogo.

18. Noterus japonicus, n. sp. Convexus, brevior, nitidus; elytris fere sine punctis majoribus impressis. Long. 2 lin.

Mas, antennis subsimplicibus; articulo $5^{\circ}$ vix incrassato, 8-10 angulo externo superiore acuto.

Closely allied to $N$. lavis; just a little shorter and more convex than that species, and with the punctures of the elytra not quite so fine. The structure of the antennæ in the male is, however, very different from that of $N$. lavis. They appear at first sight not to differ in the two sexes, but when a careful examination is made it is found that the antenna of the male is a little broader than that of the female, and that its fifth joint is just a little produced inwardly, and that joints $8-10$ have each the upper and outer angle distinctly acuminate and a little produced.

Common at Nagasaki.

19. Laccophilus Lewisius, n. sp. Formâ et staturâ fere L. testacei; testaceus, elytris nigro-lineatis, lineis haud flexuosis, aliquantum interruptis ut maculæ pallidæ ad basin et ad marginem videantur. Long. $2 \frac{1}{4}$ lin.; lat. $1 \frac{3}{4}$ lin.

About as long as L. testaceus, but just a little narrower and more convex than that species. The maxillary palpi are yellow, pitchy at the extremity; the antennæ are yellow, with the last joint pitchy, and each of the three or four penultimate joints is a little clouded at the apex. The head is yellow and unspotted. The thorax is yellow, the front margin in the middle and the hind margin have an extremely short (i. e. in the longitudinal direction of the thorax) black mark; the front one does not extend quite to the inner margins of the eyes, the hind mark is not well limited in its lateral extension; the base of the thorax in the middle is formed as in L. testaceus. The elytra are yellow, much marked with black; the black marks consist of three or four pairs of lines, the lines forming each pair meeting together a little before the base; externally, and also towards the extremity, these lines are connected with some other more or less linear markings, and the whole of these dark marks are so disposed and interrupted as to give an appearance of the elytra pos- 
sessing some yellow spots; these spots being-one on each elytron near the suture at the base, three large ones at each outer margin, and the extremity of the two wing-cases. The reticulation of the upper surface is much more evident than in L. testaceus.

A single specimen of this pretty species has been taken at Kobé, by Mr. Lewis.

20. Laccophilus flexuosus, Aubé. Common at Nagasaki. This species was described by Aubé from India. Though I have not seen any individuals from that country, I possess specimens from Persia agreeing with Aubé's description, and these I consider the same species as the Japanese individuals.

21. Laccophilus difficilis, n. sp. Ovalis, pallidus, elytris paulo obscurioribus, antennis palpisque apicibus nigro-fuscis; prothorace basi medio sat acute producto. Long. 2 lin.

This species is greatly allied to our European interruptus, testaceus, and obscurus; the base of the thorax in the middle is rather more pointed than in interruptus or testaceus, rather less than in obscurus; from interruptus its unspotted elytra and the dark extremity of the palpi and antennæ, from testaceus the latter character, and its smaller size and rather narrower form, and from obscurus its shorter and broader form, will also distinguish it; our European obscurus has the extremity of the palpi and antennæ darkened in only an obscure degree, while this character is very conspicuous in the Japanese insect. An examination of the underside shows that the length of the dilated portion of the hind coxæ is, in proportion to their width, much less than in obscurus.

Common at Nagasaki.

22. Laccophilus kobensis, n. sp. Ovalis, testaceus, elytris obscure fuscis, basi margineque sat distincte testaceomaculatis; prothoracis basi medio minus acute producto. Long. $1 \frac{2}{3}$ lin.

This species is smaller than either $L$. interruptus or obscurus, and is more allied to the former than the latter; it is somewhat similar in colour to L. interruptus, but the spots are not quite so distinctly limited, and the angle of the base of the thorax is just a little more acute. The much less acute angle of the base of the thorax, the much shorter 
and more rounded form, and the more distinctly spotted elytra, will prevent its being confounded with $L$. obscurus. Probably common at Kobé (Hiogo).

V 23. Hyphydrus japonicus, n. sp. Rufo-testaceus, capite, prothorace, elytrisque nigro-variegatis. Long. $1 \frac{7}{8}-2 \frac{1}{3}$ lin.

Mas.-Nitidus fortiter punctatus.

Femina. - a, opaca obsolete punctata.

$b$, ut in marem nitida et punctata.

This species is closely allied to $H$. variegatus. It is, however, rather smaller, proportionally a little broader, and more acuminate both in front and behind; the black markings are similar to those of $H$. variegatus, but leave a larger portion of the upper surface yellow. The punctuation is not so dense as in variegatus, and is more distinctly divided into large and small punctures. I am not aware that in variegatus a male-like form of the female has been obtained, but in japonicus the two appear to occur in about equal abundance.

H. japonicus is variable in size, in the extent of the black markings of the head and thorax, and also in the sculpture of the upper surface, but none of the varieties I have seen could at all be united with variegatus.

Common at Nagasaki and Hiogo.

24. Hydroporus japonicus, n. sp. Ex affinitate $H$. minutissimi.-Elongato-ovalis, subdepressus, supra rufotestaceus, capite prothoraceque basi plus minusve infuscatis ; elytris distincte punctulatis, fasciis longitudinalibus plus minusve coalescentibus nigris; subtus piceus. Long. 1 lin.

This little insect belongs to the same section of the genus as minutissimus and its allies; it has a deep impressed mark on each side of the thorax, and this is continued on the basal part of the elytra. The antennæ are pitchy, largely yellow at the base. The head is yellowish. The thorax is yellowish with the-base clouded in the middle, and with the dark part sparingly but distinctly punctured; the impressed lines are deep; it is a little rounded at the sides, its outline not continuous with that of the elytra; it is nearly as broad at the front angles as at the hind ones. The elytra are scarcely broader at their base than the thorax; they are a little rounded at the sides and pointed behind; they are of a yellowish colour, but much marked with black; the suture, a transverse band at the base, an 
elongate mark, not united with the sutural one except near the base, a mark below the shoulder, and another one behind this near the outer margin, black; they are rather strongly punctured on the disc. The legs are yellow. The under surface is blackish, with the breast red in the middle.

Abundant at Nagasaki.

25. Cnemidotus intermedius. Latus, testaceus, indistincte nigro-maculatus, elytris fortiter striato-punctatis ; laminis coxarum fortiter punctatis, apice valde et acute dentatis. Long. $1 \frac{3}{4}$ lin.

Closely allied to C. casus and rotundatus, and in form intermediate between the two; easily distinguished from either by the much more closely punctured ventral plates, and the large and very pointed tooth at their extremity. Thorax with a few punctures near the hind angles, some finer ones about the front, and an irregular row of larger ones along the base, this row terminating some distance from the sides by two or three larger punctures placed close together. Elytra yellow, with five or six indistinct black spots, punctate-striate, the punctuation very coarse at the base and fine at the extremity; the punctures black, the first of each row very large and deeply impressed.

Abundant at Nagasaki.

26. Haliplus japonicus, n. sp. Rufo-ferrugineus, capite infuscato, prothorace basi utrinque impresso, elytris fortiter striato-punctatis, fusco-lineatis. Long. $1 \frac{1}{2}$ lin.

Allied to $H$. ruficollis and about the same size, but scarcely so broad at the shoulders; the punctures of the striæ of the elytra much larger, the first puncture of the third, fourth, and fifth rows from the suture distinctly larger than the rest, the head infuscate and the elytra unspotted. It is not likely to be confounded with any other species I know.

Two specimens from Nagasaki.

\section{GrRINIDÆ.}

27. Gyrinus japonicus, n. sp. Ovalis, convexus, supra chalybeo-niger, lateribus ænescens, elytris æqualiter punctato-striatis, punctis apice subtilioribus; subtus niger, prothoracis et elytrorum margine inflexo æneo-ferrugineo. Long. $2 \frac{2}{3}-3 \frac{1}{2}$ lin.; lat. $1 \frac{3}{5}$ lin. 
Allied closely to our European species marinus and Suffriani. It is rather broader and more convex than marinus, and it differs from it by the punctures of the striæ, which become finer towards the extremity, and also by the absence in both sexes of the fine sculpture of the upper surface which is so distinct in the females of marinus. It is more nearly allied to Suffriani, and it much resembles that species in the punctuation of the elytra, but it is so much larger and broader that the two cannot be confounded. The internal striæ of the elytra are quite distinct, but they are a little finer than the lateral ones. The claws of the tarsi are red and unspotted; the inflexed margin of the prothorax is reddish; the epipleuræ of the elytra are æneous, a little rufescent in the middle in their basal half; the femora of the four hinder legs are pitchy in the middle.

Abundant at Hiogo and Nagasaki.

Obs.-Besides the specimens described above, I have seen two other specimens ( $\delta$ and $q$ ) of a Gyrinus from Japan (one in Mr. Lewis's collection from Nagasaki, and one from another source in my own). They may prove to be a distinct species from the above, being considerably smaller, having the inflexed margin of elytra and thorax red, and the femora entirely red. I should like to see more specimens to confirm their claim to be considered a distinct species. It is possible they may be the species intended by Motschoulsky under the name of G. curtus, but I have not been able to consult his description.

28. Dineutes marginatus, n. sp. Ovalis, supra metallescens, flavo-limbatus, subtus cum pedibus testaceus, elytris quadrispinosis, spinis internis externis haud longioribus. Long. $4-4 \frac{1}{2}$ lin. ; lat. $2 \frac{1}{3}-2 \frac{1}{2}$ lin.

Mas abdomine simplice.

Fem., abdomine segmento $2^{\circ}$ medio valde rotundatoproducto.

Allied to D. spinosus, Aubé, but larger and broader, and with the internal tooth on each elytron not broader than the external one. The upper surface is metallic, with a yellow margin extending from the front of the thorax to the first tooth of the elytra; internal to this is a greenish stripe, and inwards from this two dark purplish coppery stripes, these stripes being separated from one another by obscure striæ; at the base, near the suture, there are also traces of two of these dark copper stripes: 
when well examined, the elytra are found to possess traces of a sparing and obsolete scattered punctuation. Each elytron is armed near the extremity with two sharp moderately long spines, one placed quite at the extremity near the suture, the other at the side at a five or six times greater distance from the suture. The under surface, as well as the legs, is entirely pale yellow.

Abundant in Nipon and Kushiu. I also possess specimens of this species from Mantchuria.

\section{HYDROPHILIDA.}

29. Hydrophilus cognatus, n. sp. Ovalis, nigro-olivaceus; palpis antennarumque basi testaceis, harum clavâ fuscâ; elytris suturâ spinâ apicali minutâ instructis; abdomine segmentis medio carinatis. Long. 17-18 lin.; lat. 9 lin.

Mas, tarsis anterioribus articulo $5^{\circ}$, precedente paulo latiore.

This species is greatly allied to our European $H$. piceus, but is quite distinct therefrom; it is about the size of aterrimus; it has a minute spine at the extremity of the elytra, as in piceus, and all the segments of the abdomen are carinated along the middle. The sternal spine is deeply canaliculate in front, and again before the extremity; the portion projecting over the base of the abdomen is unmistakably shorter than in H. piceus; this character, with its smaller size, will enable the female to be distinguished from that of $H$. piceus ; the male cannot be confounded with $H$. piceus, the slightly dilated joint of the front tarsi and the comparatively small and less unequal unguiculi being very different from our European species.

Abundant in Nipon and Kushiu.

I possess this species from China and Formosa. I have not been able to see Motschoulsky's description of $H$. acuminatus from China.*

30. Hydrophilus japonicus, n. sp. Anguste-ovalis, minus convexus, supra viridi-olivaceus, plus minusve metallescens; elytrorum sutura apice denticulâ minutâ; palpis antennisque rufis; subtus niger, abdomine lateribus fulvo-maculato; processu sternali elongato; abdomine

* Since this was written I have seen the description referred to, and consider it inapplicable to either of the two species of Hydrophilus here described. D. S. 
toto pubescente, segmentibus basalibus medio minus evidenter angulatis, segmento anali omnino ecarinato. Long. 12 lin. ; lat. $5-5 \frac{1}{2}$ lin.

Mas, tarsis anterioribus apicem versus leviter dilatatis, unguiculis sat elongatis magis curvatis.

This species belongs to a group differing materially from $H$. piceus and its allies by the entirely pubescent abdomen; the species of the group form a gradual passage to the genus Temnopterus of Solier. The outlines of this insect are more continuous than in piceus: the maxillary palpi have the apical joint shorter than in piceus, and a little truncate at the extremity: the sculpture of the elytra does not become more distinct towards the extremity : the extreme apex of the elytra is not truncate, but in each it is just a little separately rounded, and the suture has a minute denticle. The sternal keel is strongly channelled, and projects backwards nearly as far as the hind margin of the third abdominal segment. The segments of the abdomen, except the apical one, are a little carinate, or rather angulate, in the middle. The legs are pitchy black; the hind femora cometimes reddish.

Rare; found at Ipongi, near Nagasaki, in paddy fields. I possess a very closely allied species from Mantchuria, and some other allied species from the Philippines; these latter have the abdominal segments in the middle furnished with some sparing setæ.

31. Hydrochares affinis, n. sp. Ovatus, sat convexus, niger, nitidus, palpis, antennis pedibusque rufo-testaceis, his femoribus basi nigris; abdominis segmentis lateribus rufo-maculatis, femoribus posterioribus subtus lævigatis. Long. $8 \frac{1}{2}$ lin.; lat. $4 \frac{1}{3}$ lin.

Closely allied to our European species caraboides and flavipes; it is of the same size and form as $H$. caraboides, and has the punctuation of the upper surface similar, but it is distinguished therefrom by the red legs, and the impunctate hind femora; from $H$. flavipes it is distinguished only by its larger size and broader form, and by the fact that in $H$. affinis the striæ of the elytra are quite distinct, though very fine, whereas they are very nearly absent in flavipes.

I have seen only two specimens of this species; one of them, very soft and immature, has the upper surface olivaceous, the other is black.

Found in a pond at Hiogo. 
32. Hydrochares favipes, Stev. var. A single specimen found at Nagasaki is so close to our European H. flavipes, that I think it may perhaps prove a mere variety thereof.

33. Sternolophus fulvipes, Mots.?* A species of Sternolophus is common in Nipon and Kushiu; though I have not been able to see Motschoulsky's description of S. fulvipes, I think it so likely that this insect is what he intended thereby that I do not describe it as new.

34. Philhydrus japonicus. Ovalis, convexus, nitidus, niger, palpis, antennis basi, clypeo maculâ utrinque, et prothoracis elytrorumque lateribus testaceis, pedibus piceis, tarsis dilutioribus; crebre sat fortiter punctatus, elytris obsoletissime striatis, seriebus tribus punctorum majorum. Long. 3 lin. ; lat. $1 \frac{3}{5}-1 \frac{2}{3}$.

Rather larger and notably broader than P. testaceus. Palpi yellow. Head black, with a narrow, but distinct, yellow spot on each side in front of the eye; closely and rather strongly punctured. Thorax black, with the sides very distinctly yellowish, the yellow colour also extending along the front margin, so that the extreme front margin is pale; the pale colour also extends inwards along the hind margin, but more indistinctly; closely and distinctly punctured, on each side with some larger punctures forming a not very distinct horse-shoe curve. Elytra black, distinctly margined with yellow, rather strongly and closely punctured, the punctures not quite so numerous at the extremity as at the base; they have a sutural stria abbreviated at the base; they also present indistinct traces of being striate-punctate, and moreover have three series of larger punctures, of which the outer is not so well defined as the other two. Beneath the femora are black and pubescent, except the extremity, which is reddish and impunctate. The tibiæ are pitchy; the tarsi yellowish. The mesosternal carina strongly elevated, acuminate below.

Nagasaki.

35. Philhydrus simulans, n. sp. Ovalis, sat convexus, supra testaceus, capite postice nigro; sat crebre fortiter punctatus, elytris fortiter striatis, striis internis basi obsoletis, interstitiis $3,5,7,9$, serie punctorum majorum :

* I find this species cannot be reconciled with Motschoulsky's description of $S$. fulvipes here alluded to. I am sorry to say, however, that I cannot decide whether the Japanese insect be the same as the Indian S. rufipes, Fab., or not. D. S. 
subtus niger, pedibus testaceis, femorum margine posteriore nigricante. Long. $2 \frac{1}{4}$; lat. $1 \frac{1}{4}$ lin.

Maxillary palpi yellow ; the apex of the last joint slightly infuscate. Head closely and rather finely punctured, the front part yellow, the hind part black. Thorax yellowish, the disc a little clouded; it is rather finely and closely punctured, and has near each side a curved irregular patch of larger punctures. Elytra yellowish, not so densely punctured as the thorax, rather strongly striated, the sutural stria not reaching to the base, and the two or three next to it extremely indistinct at the base; from the third to the ninth each alternate interstice bears some larger punctures. The underside is black, the legs yellow; the femora darker behind, pubescent beneath, except at the extremity of each; hind tarsi long and slender; carina of the mesosternum largely developed, its front angle acute.

A single specimen only of this species has been taken by Mr. Lewis at Nagasaki; this is the only Philhydrus I have ever seen with distinctly striated elytra, though I know several species of Helochares sculptured in that way.

36. Helochares striatus, $\mathrm{n}$. sp. Ovalis, minus depressus, rufo-testaceus, capite nigricante maculâ utrinque rufotestaceâ ; crebre fortiterque punctatus, elytris fortiter punctato-striatis; subtus obscure rufescens, tibiis tarsisque testaceis. Long. $2 \frac{1}{3}$ lin.; lat. $1 \frac{1}{3}$ lin.

Maxillary palpi entirely yellow, considerably shorter than in H. lividus, but similarly formed. Head blackish, yellow on each side in front of the eyes, coarsely and rather closely punctured. Thorax with the punctuation similar to that of the head, the lateral margin coarser behind than in front. Elytra rather less strongly punctured than the head and thorax, each with ten striæ of rather deeply impressed punctures, a short abbreviated row of punctures between the scutellum and first stria ; the striæ do not extend quite to the outside, but leave a distinct margin much directed outwards. The under surface is pubescent and pitchy red; the elytra greatly overlap the hind body; the mesosternum has a slightly elevated tubercle in front. The tibiæ and tarsi are yellow.

I have seen but a single specimen of this very distinct and interesting species; it was found by $\mathrm{Mr}$. Lewis at Nagasaki.

I possess allied species from Australia and Cochin China.

37. Helochares Lewisius, n. sp. Ovalis, nitidus, sub- 
depressus, supra testaceus, capite prothoraceque crebre minus fortiter, elytris crebre subtiliter, punctatis; subtus fuscus, pedibus testaceis, femoribus obscurioribus. Long. $1 \frac{1}{5}-1 \frac{1}{2}$ lin.

Allied to $H$. dilutus, Er., but not one quarter its size, of a purer yellow colour above. The palpi are entirely yellow. The head and thorax are closely and finely punctured, the latter finely margined at the sides. The elytra are very finely punctured, and each has a row of larger punctures along the middle. The underside is fuscous, the mesosternum obscurely tuberculated. The legs are yellow, the femora pubescent except at the extremity, the pubescent part darker in colour.

Nagasaki and Hiogo.

38. Laccobius minutus, Lin. Nagasaki. The specimens differ a little from our European ones, but I do not perceive any sufficient characters to distinguish them as a species.

39. Berosus japonicus, n. sp. Ovalis, convexus, supra sordide testaceus, capite viridi-æneo, prothorace disco maculâ geminatâ (vel quadrigeminâ) parvâ; elytris obscure nigro-maculatis, fortiter punctato-striatis, interstitiis parce punctatis; antennis, palpis, pedibusque testaceis. Long. $2 \frac{1}{2}$ lin.

This species is closely allied to B. signaticollis, Charp.; it is rather smaller than that species, and has the elytra shorter and rather more deeply striate; it is readily distinguished by the greater extent of the pubescence on the under surface of the femora: on the hind femur of $B$. signaticollis the pubescence does not extend more than half way to the extremity, while in japonicus only the apical third is glabrous. The spots on the disc of the thorax are small and not united in the middle, and sometimes they are separated transversely so as to form four small spots.

Nagasaki.

40. Berosus (Enopleurus) Lewisius, n. sp. Oblongoovalis, supra pallide testaceus, crebre fortiterque punctatus, capite vertice, prothoraceque disco utrinque minus evidenter fusco-maculatis; elytris crenato-striatis, interstitiis crebre punctatis, parce brevissime setigeris; antennis, pedibus palpisque testaceis, his apice extremo infuscato. Long. $2 \frac{1}{5}$ lin; lat. 1 lin. 
Head closely and rather deeply punctate, the vertex with a double fuscous spot. Thorax closely and coarsely punctured; on each side of the disc is a very small space, from which the punctures are absent; it is of a pale yellow colour, with a very indistinct and ill-defined cloudy marking on each side the middle; the elytra are pale, with three or four very indistinct black spots on each, they are deeply crenate-striate; the interstices are finely and moderately closely punctured, each puncture bearing a very short fine hair; the suture is prolonged at the apex into a sharp tooth, and each has also outside this a long and sharp spine, placed rather farther from the suture than usual. Legs pale yellow.

I have seen but a single specimen of this species taken at Nagasaki.

I possess several species of this section from China and Australia, but nothing closely allied to this.

41. Volvulus profundus, n. sp. Anguste ovalis, valde elevatus, supra æneus, nitidus, crebre punctatus, elytris punctato-striatis, striis internis basi obsoletis; antennarum basi, palpisque testaceis, his apice summo piceo; subtus niger; pedibus nigro-piceis, tibiis tarsisque anterioribus rufo-testaceis. Long. 2 lin.; lat. 1 lin.

Much smaller than $V$. inflatus, and above entirely brassy. Maxillary palpi yellow, the last joint about twice as long as the preceding one, pitchy at its extremity. Antennæ yellow, with the club dark. Head densely and finely punctured, behind the labrum more densely and finely than at the vertex. Thorax as wide as the elytra, with the base rounded, the posterior angles absent; it is densely and rather finely punctured. Scutellum narrow and elongate, finely punctured. Elytra moderately densely and finely punctured, each with ten striæ deeply impressed at the extremity, the three or four internal ones not visible at the base. Under surface black, the mesosternum very strongly carinated, the two hinder pair of femora pitchy, strongly punctured and glabrous beneath. Anterior tibiæ and tarsi obscurely yellowish.

Abundant everywhere.

I possess a very closely-allied species from several localities in the Malay Archipelago.

42. Amphiops mater, n. sp. Perconvexus, subhemisphæricus, piceus, capite, prothoraceque creberrime 
subtiliter punctulatis; elytris striato-punctatis, striis internis subtilioribus, palpis tarsisque testaceis. Long. $1 \frac{1}{2}-$ 2 lin.

Maxillary palpi yellow, last joint longer than the preceding one; the antepenultimate joint distinctly thickened. Head very broad, margined along the front, densely and finely punctured, especially in front, and with some irregularly placed larger punctures. Thorax densely and rather finely punctured, with a few indistinct larger punctures scattered about it. Elytra externally with some rows of coarse punctures; the internal ones are very fine, and only to be seen towards the extremity, where it is found that the rows are placed obliquely, so that the inner ones end near the suture some distance before the apex; the external interstices have each a row of coarse punctures, and also some finer punctures. The underside has only an extremely sparing and fine, scarcely visible, pubescence. The legs are yellowish or pitchy yellow, the tarsi yellow, the posterior tarsi slender, and not at all remiform. The intermediate coxæ are considerably separated, the mesosternum not carinate.

Taken at Hiogo and Nagasaki.

This insect is one of great interest from a peculiar structure of the abdomen, which has not yet been remarked. On the abdomen being taken off it is found that the first segment.is placed at right angles with the others (the abdomen is perhaps flexible there), so that in life the hinder segments are turned upwards, and leave a large vacant space underneath the elytra. In one large specimen I have examined, no doubt a female, the abdomen at first sight appears to be entirely wanting. It is very possible that this structure enables the insect to carry about its eggs on dry land; it is, I have no doubt, at best only a semi-aquatic species, for it is not provided with pubescent portions on the under surface to retain air, as are the more aquatic palpicorns. This peculiar abdominal structure must be considered in connection with the inflated elytra, and also with the fact that the hind coxæ are transverse and largely developed, and free both above and below; add to this, that where the posterior legs are flexed an additional protection is given by them to the subelytral space. Observations on the habits of this species would, I have no doubt, be of great interest.

I am indebted to Mr. H. W. Bates for a closely allied 
species from China. The relationship of the genus to Cyclonotum is evident.

43. Hydrochus japonicus, n. sp. Supra viridi-metallicus, palpis piceis; subtus niger, pedibus testaceis, femorum basi piceis; thorace foveolato, elytris interstitiis minus evidenter elevatis. Long. $1 \frac{1}{3}-1 \frac{1}{2}$ lin.

Smaller than either of our European species, somewhat similar in colour to $H$. angustatus; distinguished by the prothoracic foveæ, which appear separated from one another, as it were, by raised lines. Head and thorax metallic green or blue, the latter with five or six foveæ, occupying the greater part of its upper surface, placed very close to one another, so as to appear separated only by narrow linear elevations; the elytra are metallic, but not so brilliant in colour as the head and thorax; they are coarsely, closely, and regularly punctate-striate, the third and fifth interstices elevated, but not strongly; the fifth also elevated at the base; the under surface is silky, opaque, and blackish; the legs are yellow, the femora rather darker, especially at the base.

Common at Nagasaki.

44. Cyclonotum latum, n. sp. Sat convexum, nitidum, nigrum, palpis, antennis, tarsisque rufis, pedibus piceis; subtiliter sat crebre punctatus: elytris evidenter striatopunctatis. Long. $3 \frac{1}{2}$ lin.; lat. 2 lin.

The broad, comparatively short form of this species is remarkable. The head is closely and rather finely punctured, especially in front; the thorax is finely and not densely punctured; it is fully three times as broad as long. The punctuation of the elytra is similar to that of the thorax, perhaps scarcely so close or distinct. Each is also furnished with ten distinct rows of punctures; these are coarser and more distinctly impressed at the extremity than at the base. The under surface is densely and finely punctured, pubescent, and opaque, except the central part of the metasternum; the prosternum is very acutely elevated in the middle in front. The legs are pitchy, the tarsi reddish.

I have seen but two specimens of this species taken at Nagasaki, where Mr. Lewis tells me it is common in ponds.

I possess an allied species, with punctate-striate elytra, 
from Penang; in it the punctuation of thorax and elytra is much denser.

45. Cercyon dux, n. sp. Ovalis, leviter convexus, minus nitidus, niger, antennis, pedibus, palpisque piceorufis, prothorace lateribus castaneis, elytris colore variabilibus; dense punctatus; elytris striatis, striis postice profundioribus. Long. $1 \frac{3}{4}-2$ lin.

This fine species is allied to C. littoralis, but has the anterior tibiæ simple at the extremity: it is remarkable for the dense and even punctuation of the elytra; these are either of a chestnut colour, or black, with the margins paler; the strix are very deeply impressed towards the apex. The mesosternum has the intercoxal process very long; the prosternum is carinate along the middle, and the basal segment of the abdomen is finely carinate; the whole of the under surface is pubescent and opaque, except the pentagonal portion of the metasternum and the mesosternal process; these are shining, and distinctly and rather closely punctured. This and the following species evidently belong to the genus Pelosoma of Mulsant, which will, perhaps, ultimately have to be adopted as a good genus.

Seaweed. Nagasaki and Amakusa.

46. Cercyon algarum, n. sp. Ovalis, leviter convexus, nitidus, niger, antennis, palpis, pedibusque rufis; capite prothoraceque sat crebre punctulatis, elytris striatis, striis apicem versus profundioribus, intestitiis parce subtiliter punctulatis. Long. 1 lin.

Allied to $C$. littoralis, but with the anterior tibiæ simple at the apex, the punctuation of the interstices of the elytra finer and more scanty; the strix are very deeply impressed towards the extremity. The structure of the under surface is similar to that of $\boldsymbol{C} . d u x$, the pentagonal space very finely and sparingly punctured.

Of four specimens I have seen, three have the elytra black, with only their very extremities paler ; in the other specimen the colour of the elytra is pitchy; the species is probably very variable in colour, like its allies; the legs are furnished with fine short spines.

Under seaweed in company with $C$. $d u x$.

47. Cercyon aptus, n. sp. Ovalis, leviter convexus, nitidus, colore variabilis, antennis, palpis, pedibusque testa-

TRANS. ENT. SOC. 1873.-PART I. (MAR.) 
ceis; elytris striatis, striis apice profundioribus, interstitiis subtilissime sat crebre punctulatis, alternis apicem versus paulo magis convexis; tibiis dense fortiterque spinulosis. Long. $1 \frac{1}{3}$ lin.

Again allied to $C$. littoralis, but smaller, with the anterior tibiæ simple at the extremity, and the punctuation of the upper surface finer. It is allied to the preceding species, but is longer and very distinct therefrom by the armature of the tibiæ, the spines thereon being much more largely developed. The convexity of the alternate interstices of the elytra towards the extremity, though only slight, cannot be overlooked on a careful examination. The two specimens before me are discordant in colour, one being of a yellowish colour, the other pitchy, with the margins and extremities of the elytra paler.

Nagasaki and Hiogo; no doubt from under seaweed.

48. Cercyon laminatus, n. sp. Piceus, lateribus dilutior, capite nigro, antennarum basi, pedibus, palpisque testaceis, his articulo ultimo infuscato; crebre sat fortiter punctatus; elytris punctato-striatis, striis apice profundioribus. Long. $1 \frac{3}{4} \operatorname{lin}$.

This species differs from the others of the genus, by the intermediate legs being separated only by a thin lamina, as in the genus Philhydrus. Maxillary palpi yellow, with the last joint infuscate. Antennæ with the base yellow, the club fuscous and very elongate. Head black, rather strongly and closely punctured. Thorax pitchy, more transparent along the front and sides, rather closely and strongly punctured. Scutellum very narrow. Elytra pitchy, paler yellow at the sides and extremity, deeply punctate-striate, the striæ deeply impressed behind, the punctuation of the insterstices distinct, but more sparing than that of the head and thorax. The legs are yellow, with the tarsi long; the tibiæ of the four front legs rather strongly, the hind ones more feebly, spined.

I have seen but two individuals of this very distinct species. Though it has completely the appearance of a Cercyon allied to littoralis, it may possibly prove the type of a new genus. Found in dung at Hiogo.

49. Megasternum distinctum, n. sp. Ovatum, valde convexum, nitidum, nigrum, lateribus dilutior, antennis basi, palpis pedibusque rufis; elytris punctato-striatis, 
interstitiis minus crebre punctulatis; tibiis anticis integris. Long. $1 \frac{1}{3}-1 \frac{1}{2}$ lin.

This insect is similar in form and colour to Megasternum boletophagum, but is greatly larger; it is similar to that species in the structure of its under surface, but has the anterior tibia simple at the extremity; as this character is only a sectional one in Cercyon, it cannot here be considered of sufficient importance to justify the establishment of a new genus.

The head and thorax are rather strongly and closely punctured, the latter with a row of larger punctures placed along the base. The elytra are moderately strongly punctate-striate, the insterstices very finely punctured. The under surface is coarsely and closely punctured.

Two specimens without special locality. 


\section{$2 \mathrm{BHL}$ Biodiversity Heritage Library}

Sharp, David. 1873. "III. The Water Beetles of Japan." Transactions of the Entomological Society of London 21, 45-67. https://doi.org/10.1111/j.1365-2311.1873.tb00636.x.

View This Item Online: https://www.biodiversitylibrary.org/item/51216

DOI: https://doi.org/10.1111/j.1365-2311.1873.tb00636.x

Permalink: https://www.biodiversitylibrary.org/partpdf/33377

\section{Holding Institution}

Smithsonian Libraries

\section{Sponsored by}

Smithsonian

\section{Copyright \& Reuse}

Copyright Status: Public domain. The BHL considers that this work is no longer under copyright protection.

This document was created from content at the Biodiversity Heritage Library, the world's largest open access digital library for biodiversity literature and archives. Visit BHL at https://www.biodiversitylibrary.org. 